\title{
Production effects related to mastitis and mastitis economics in dairy cattle herds
}

\author{
Henri SeEgers*, Christine Fourichon, François BeAudeau \\ Unit of Animal Health Management, UMR 708 ENVN/INRA, National Veterinary School, BP 40706, \\ 44307 Nantes Cedex 03, France
}

(Received 17 December 2002, accepted 27 May 2003)

\begin{abstract}
Mastitis is the most prevalent production disease in dairy herds world-wide and is responsible for several production effects. Milk yield and composition can be affected by a more or less severe short-term depression and, in case of no cure, by a long-acting effect, and, sometimes, an overlapping effect to the next lactation. Summary values in the literature for losses of milk production were proposed at $375 \mathrm{~kg}$ for a clinical case (5\% at the lactation level) and at $0.5 \mathrm{~kg}$ per 2 -fold increase of crude SCC of a cow. Due to the withdrawal period after treatment, composition changes in milk can almost be neglected in economic calculations. Lethality rate for clinical mastitis is very low on the average, while anticipated culling occurs more frequently after clinical and subclinical mastitis (relative risk between 1.5 and 5.0). The economics of mastitis needs to be addressed at the farm level and, per se, depends on local and regional epidemiological, managerial and economic conditions. To assess the direct economic impact of mastitis, costs (i.e. extra resource use) and losses (i.e. reduced revenues) have to be aggregated. To support decision making for udder health control, it is necessary to use a marginal approach, based on the comparison of the losses avoided and the additional costs of modified plans, compared to the existing ones.
\end{abstract}

dairy cattle / mastitis / milk somatic cell count / milk yield / longevity / economics

Table of contents

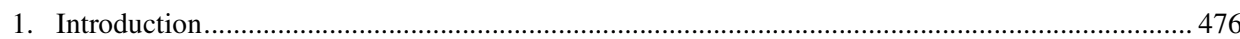

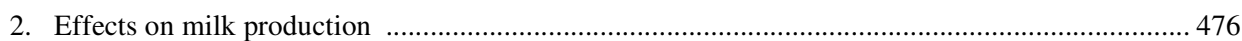

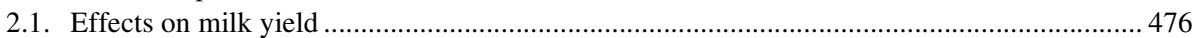

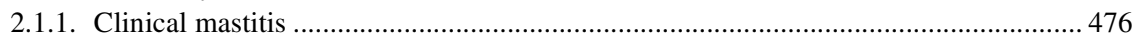

2.1.2. Elevated somatic cell counts ............................................................................. 479

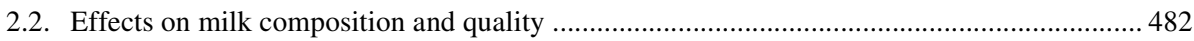

3. Effects on longevity and other production effects .................................................................. 482

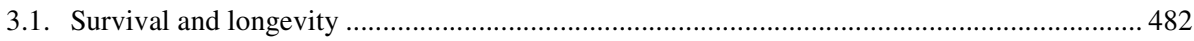

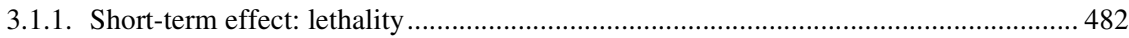

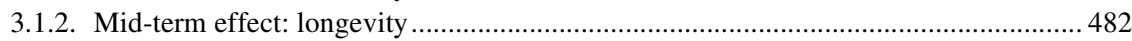

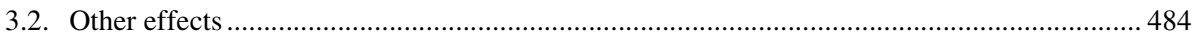

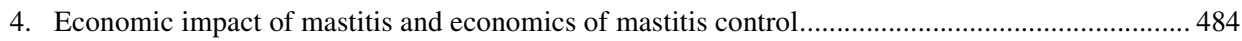

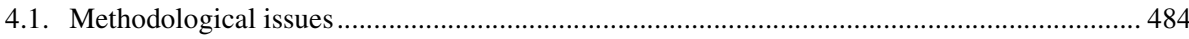

\footnotetext{
* Corresponding author: seegers@ vet-nantes.fr
} 
4.2. Recent examples of questions studied and results

\section{INTRODUCTION}

Mastitis is considered to be the most frequent and most costly production disease in dairy herds of developed countries (e.g. [24, $44,50])$. The assessment of the economic worthiness of a control programme for mastitis has to be supported by a reliable evaluation of the economic losses caused by the disease and the knowledge of the costs of the implementation of that programme. The losses are revenues not earned, while the control costs are real expenditures [42]. Sometimes economic calculations use unrealistic estimates of production losses associated for mastitis and an over-estimated impact. This can then lead to a wrong decision, seen from an economic point of view.

The decrease in milk production per cow due to the clinical and subclinical prevalence of mastitis is usually recognised as the main pathway in causing the economic losses due to the disease $[16,53]$. Although, this primordial place may sometimes be challenged under a strict quota limitation, as in France [57]. Previously published papers about the effect of mastitis on milk yield and composition are quite abundant and several discrepancies between the estimated yield losses have been reported [31, 32]. Other production effects (sensu largo) of mastitis, i.e. mainly reduced longevity and short term lethality, also have to be taken into account to assess the economic losses, but they have not been documented so much. The effects on body weight and feed intake have only been scarcely studied, and are therefore never quite integrated into the economic calculations. Other components of economic losses of mastitis generally included in the calculations are penalties or loss of premiums related to the somatic cell count of the bulk tank milk and the milk withdrawn during and after antibiotic treatment. To obtain the total economic impact (sometimes so-called total cost) of mastitis, all these losses (revenues not earned) are added to the control costs (actual expenditures related to treatments and preventive measures, and extra labour to apply them) [42].

The aim of this paper was to provide a summary view of the recent papers published on the production effects and economics of mastitis, considering only on-farm consequences and not addressing public health or dairy processing concerns. Due to an intrinsic non-comparability of the results from economic studies under different production systems and prices contexts [55], our review will be limited to a methodological discussion and examples of that aspect.

\section{EFFECTS ON MILK PRODUCTION}

\subsection{Effects on milk yield}

\subsubsection{Clinical mastitis}

The effects of clinical mastitis on milk production were last reviewed by Hortet and Seegers [31] and only two papers were published thereafter [46, 51].

All the studies relied on observational designs. Large samples (in terms of the number of herds included) were generally samples where only a monthly measurement of individual milk yield was done, whereas samples consisting of a small number of herds had a more frequent milk yield measurement. Almost all clinical cases considered in the reviewed studies were treated cases. The assessment of loss 
in milk yield (not including the withdrawal of milk due to treatment, which depends on local regulations) was performed using several time-frames of study: lactation, shorter periods, or long-term effects by including inter-lactation carry-over effects, and using several types of comparison or modelling approaches [31].

The main recent results (literature published since 1990) for lactational-level yield losses are displayed in Table I. Of course, these estimates depend on the average time of occurrence within the lactation, which is probably not comparable between the different studies. Estimates of average lactational loss due to a clinical case ranged from non significant or very low values in some studies to values higher than $700 \mathrm{~kg}$ of milk in others.

The results for short term estimates of yield loss (Tab. II) ranged from 0 to $100 \mathrm{~kg}$ of milk, when reassessed on a monthly basis around or following occurrence. Higher estimates (40 to $160 \mathrm{~kg}$ per month) for monthly loss were found for calculation periods longer than two months (Tab. II). Recently, this observation was confirmed by the results of Østergaard and Gröhn [46]. Figure 1 shows first, that in this study, multiparous cows experiencing clinical mastitis were higher producing cows and that, therefore, losses were underestimated (a shifted curve has been added in the figure to illustrate this). Figure 1 also shows that the magnitude of loss reincreased from the second week postoccurrence. This profile is probably related to a beneficial effect of treatment during a few days after occurrence, followed, in some cows, by a resumption of infection and a chronic expression.

The internal validity of the provided estimates depends on the relevance of the models used and, especially, on how the fact that the production level is also a risk factor for clinical mastitis is handled [34]. Moreover, the main weakness of the published results is the unavoidable bias of selection due to the fact that the most severe cases cannot be truly studied when the short term fatality risk is not null and when a very strong depression of milk yield can lead to very early culling. Only Lescourret and Coulon [40] tried to account for these cases by simply considering that the production loss was total after death or culling.

Regarding the external validity, in addition to the previously underlined differences in statistical modelling approaches, some likely differences between study samples probably generate normal discrepancies, for instance: differences in the prevalence of the pathogens involved, in clinical case definition, in the efficacy of treatments, etc.

Remaining questions and areas for further research are numerous:

(1) How to deal relevantly with the production level as a risk factor for the occurrence and factor of underestimation? Several attempts have been made to compare a modelled/expected yield to the observed yield. However, using previous lactation performance or previous test-day results to predict the expected yield does not avoid the drawback (in small or mid-sized samples) that unrecorded effects on yield can interfere. Moreover, this approach cannot be done for primiparous cows or early lactation.

(2) The effects of parity and lactation stage at the occurrence still remain unclear: the results are controversial, especially regarding parity, when comparing those of Houben et al. [34] and Rajala-Schultz and Gröhn [50], for instance.

(3) The same lack of research exists for carry-over effects from a lactation to the following one: only Houben et al. [34] recently studied this aspect. This question probably has to be combined with that of the assessment of differences due to the involved pathogens. The literature reports only non significant differences between pathogens. However, the samples were small, leading to a possible lack of power (in Bartlett et al. [6] and Wilson and Sears [63]). 
Table I. Summary of study samples and the results in studies dealing with milk loss due to clinical mastitis at lactation level and published since 1990 (partly taken from Hortet and Seegers [31]).

\begin{tabular}{|c|c|c|c|c|c|c|}
\hline \multirow[t]{2}{*}{ Reference } & \multicolumn{3}{|c|}{ Animals } & \multicolumn{2}{|c|}{ Loss } & \multirow[t]{2}{*}{ Comment } \\
\hline & $\overline{\text { Parity }}$ & Milk (kg/lact) & Breed $^{\mathrm{a}}$ & Mean (kg) & $\%$ & \\
\hline $\begin{array}{l}\text { Houben et al. [34] } \\
\text { (3) }\end{array}$ & 1 & 6433 & $\mathrm{H}$ & 31 to 128 & 0.5 to 2.0 & $\begin{array}{l}\text { Effect of } 1 \text { to } \geq 3 \\
\text { quarter-cases within } \\
\text { current lactation }\end{array}$ \\
\hline $\begin{array}{l}\text { Myllys and Rautala } \\
\text { [45] }\end{array}$ & 1 & 5564 & A \& F & 32.8 & 0.6 & $\begin{array}{l}\text { Mastitis only from } \\
7 \text { d. before to } \\
7 \text { d. after calving }\end{array}$ \\
\hline Pedraza [48] & 1 & 4639 & $\mathrm{H}$ & 749 & $-\mathrm{b}$ & \\
\hline $\begin{array}{l}\text { Rajala-Schultz and } \\
\text { Gröhn [50] }\end{array}$ & 1 & & A & $\begin{array}{l}294,348 \\
110\end{array}$ & $-^{\mathrm{b}}$ & $\begin{array}{c}\text { Effect of occurrence } \\
\text { before peak, between } \\
\text { peak and } 120 \mathrm{~d} \text {. and } \\
\text { later, respectively }\end{array}$ \\
\hline Houben et al. [34] & 2 & 7632 & $\mathrm{H}$ & 155 to 448 & 2.0 to 5.8 & $\begin{array}{l}\text { Effect of } 1 \text { to } \geq 3 \\
\text { quarter-cases within } \\
\text { current lactation }\end{array}$ \\
\hline Wolf and Jahnke [64] & 2 & 4572 & $\mathrm{H}$ & 205 & 4.4 & \\
\hline $\begin{array}{l}\text { Rajala-Schultz and } \\
\text { Gröhn [50] }\end{array}$ & 2 & & A & $\begin{array}{l}284,300 \\
220\end{array}$ & $-\mathrm{b}$ & $\begin{array}{c}\text { Effect of occurrence } \\
\text { before peak, between } \\
\text { peak and } 120 \mathrm{~d} \text {. and } \\
\text { later, respectively }\end{array}$ \\
\hline Firat [23] & $\geq 2$ & 6027 & $\mathrm{H}$ & 231 & 3.8 & \\
\hline Pedraza [48] & $\geq 2$ & 5256 & $\mathrm{H}$ & 734 & $-^{\mathrm{b}}$ & \\
\hline Houben et al. [34] & 3 & 8286 & $\mathrm{H}$ & $\mathrm{NS}^{\mathrm{c}}$ & NS & $\begin{array}{l}\text { Effect of } 1 \text { to } \geq 3 \\
\text { quarter-cases within } \\
\text { current lactation }\end{array}$ \\
\hline $\begin{array}{l}\text { Rajala-Schultz and } \\
\text { Gröhn [50] }\end{array}$ & 3 & & A & $\begin{array}{l}509,352 \\
387\end{array}$ & $-{ }^{b}$ & $\begin{array}{c}\text { Effect of occurrence } \\
\text { before peak, between } \\
\text { peak and } 120 \mathrm{~d} \text {. and } \\
\text { later, respectively }\end{array}$ \\
\hline $\begin{array}{l}\text { Rajala-Schultz and } \\
\text { Gröhn [50] }\end{array}$ & $>3$ & & A & $\begin{array}{c}552,329 \\
357\end{array}$ & $-\mathrm{b}$ & $\begin{array}{c}\text { Effect of occurrence } \\
\text { before peak, between } \\
\text { peak and } 120 \mathrm{~d} \text {. and } \\
\text { later, respectively }\end{array}$ \\
\hline Hoblet et al. [30] & all & 8430 & $\mathrm{H} \& \mathrm{~J}$ & 75-206 & $0.9-2.4$ & \\
\hline $\begin{array}{l}\text { Lescourret and } \\
\text { Coulon [40] }\end{array}$ & all & 5032 & $\mathrm{H} \& \mathrm{M}$ & $313 \pm 207$ & 6.2 & $\begin{array}{l}\text { Summarised by } \\
\text { reviewers }\end{array}$ \\
\hline
\end{tabular}

a H: Holstein-Friesian or Friesian; A: Ayrshire; J: Jersey; M: Montbéliarde.

$\mathrm{b}-$ : Calculation not applicable due to no data on incidence rate or lactational yield presented in the paper.

c NS: not significant. 
Table II. Short-term milk-yield loss due to clinical mastitis (partly taken from Hortet and Seegers, [31]).

\begin{tabular}{|c|c|c|c|}
\hline \multirow[t]{2}{*}{ Reference } & \multirow{2}{*}{$\begin{array}{l}\text { Lactation stage } \\
\text { at occurrence }\end{array}$} & \multicolumn{2}{|r|}{ Losses } \\
\hline & & Mean $(\mathrm{kg})$ & Duration or estimation period \\
\hline \multirow[t]{2}{*}{ Bartlett et al. [6] } & $\leq 150 \mathrm{DIM}$ & 113 & Cumulated for 60 days $\mathrm{PMO}^{\mathrm{a}}$ \\
\hline & $>150 \mathrm{DIM}$ & 72 & Cumulated for 60 days PMO \\
\hline \multirow[t]{2}{*}{ Deluyker et al. [19] } & 1-21 DIM & 127.6 & 0-49 days \\
\hline & 50-119 DIM & 250.1 & 0-79 days \\
\hline \multirow[t]{4}{*}{ Houben et al. [34] } & $1 \mathrm{WBC}^{\mathrm{b}}$ to $5 \mathrm{WIM}^{\mathrm{c}}$ & 14 to $235^{d}$ & Cumulated for 5 WIM \\
\hline & $1 \mathrm{WBC}$ to $14 \mathrm{WIM}$ & 0 to $444^{\mathrm{d}}$ & Cumulated for 14 WIM \\
\hline & $1 \mathrm{WBC}$ to $23 \mathrm{WIM}$ & 47 to $511^{d}$ & Cumulated for 23 WIM \\
\hline & All stages & mainly $\mathrm{NS}^{\mathrm{e}}$ & $\begin{array}{l}\leq 1 \text { month } \\
\text { significant decrease in only some stages } \\
\text { of lactation in parities } 1 \text { and } 3\end{array}$ \\
\hline \multirow[t]{3}{*}{ Luquet et al. [41] } & $<$ peak & NS & $\leq 4 \mathrm{wk}$ on average \\
\hline & $>5$ and $\leq 10 \mathrm{WIM}$ & $1.24 / \mathrm{d}$ & $<5$ wk on average \\
\hline & $>10$ WIM & $0.83 / \mathrm{d}$ & $<5$ wk on average \\
\hline $\begin{array}{l}\text { Wilson and Sears } \\
{[63]}\end{array}$ & NA & 4.3 & $\begin{array}{l}\text { Estimated from } 7 \mathrm{~d} \text {. before to } 14 \mathrm{~d} \text {. after } \\
\text { case occurrence }\end{array}$ \\
\hline $\begin{array}{l}\text { Østergaard and } \\
\text { Gröhn [46] }\end{array}$ & All stages & $\begin{array}{l}65 \text { (primiparous) } \\
117 \text { (multiparous) }\end{array}$ & $\begin{array}{c}\text { Estimated on } 9 \text { weeks (including } \\
3 \text { weeks before case occurrence) } \\
\text { in energy corrected milk } \\
\text { Main loss was after occurrence: } \\
\text { see also Figure } 1\end{array}$ \\
\hline
\end{tabular}

\footnotetext{
a PMO: post mastitis occurrence.

b WBC: week before calving.

c WIM: week in milk.

d 1 to $\geq 3$ quarter-cases (1st, 2 nd or 3rd lactation) without case in previous lactation.

e NS: not significant.
}

(4) What is the most-relevant way to express the losses: $\mathrm{kg}$ or $\%$ ? Or, in other terms, does the production level affect the magnitude of losses? Until now, this has never been correctly answered, despite the availability of new sophisticated statistical packages (repeated measures, multilevel modelling, ...) that could possibly help.

(5) What would have been the losses in the absence of treatment, or what is the true impact of treatment on yield losses? No real work on this question has been performed.

To summarise, a reasonable (and probably underestimated) average cumulated loss of $375 \mathrm{~kg}$ (about $5 \%$ ) can be proposed for a so-called average clinical case, occurring in the second month of lactation in a Holstein cow. However the losses are very variable. To take this variability into account, it can be proposed that out of 10 cases, 4 lead to a quite negligible loss, 5 to an average loss, and 1 case to a very high loss (about $1000 \mathrm{~kg}$ ) [31].

\subsubsection{Elevated somatic cell counts}

The effects of an elevated somatic cell count (SCC) on milk production were last reviewed by Hortet and Seegers [32] and 


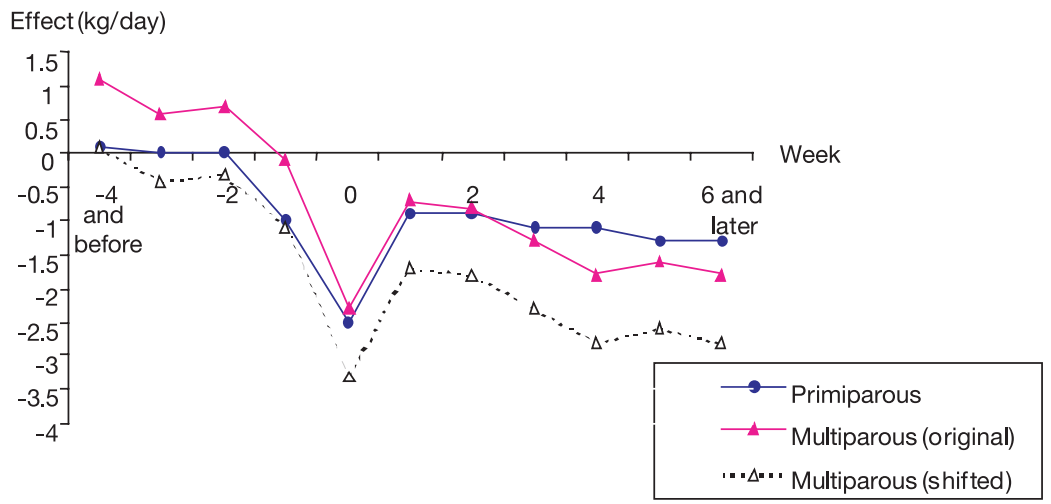

Figure 1. Profiles for daily energy corrected yield in cows with a clinical mastitis case around the week of occurrence (week 0) in deviation from the yield of non-mastitic cows [46]. The shifted curve (broken line) for multiparous cows (effect - $1 \mathrm{~kg}$ ) was drawn by review authors.

only two papers have been published since $[33,37]$.

All the studies used retrospective dataanalysis protocols. The assessment of the loss in milk yield was almost done ignoring the clinical cases (except in Hortet et al. [33] and also in Koldeweij et al. [37] who selected lactation sequences without clinical cases). The calculations relied on regression models at the test-day level, or, less frequently, at the lactation level. As for clinical mastitis, two main types of comparisons were performed: yield in test-days with vs. without elevated SCC or the expected yield vs. the observed one. As described in detail in the review of Hortet and Seegers [32], the variables used to describe SCC in the regression models differed. SCC values were mainly logtransformed or categorised, to be used as continuous or categorical independent variables. Except for the stage of lactation, the other independent regression variables included in the models differed widely.

To express a loss, the definition of a socalled "non infected" level of SCC is needed, allowing to compare milk yield in this category to that in higher SCC level categories. This "non infected" level can relevantly be set to $\leq 50000$ cells $/ \mathrm{mL}$, based on Laevens et al. [39] and Schepers et al. [54], in contemporary Holstein cows and herds with a low prevalence. However, most of the results are only expressed for one unit of increase in $\log (\mathrm{SCC})$ or for a two-fold increase of crude SCC. This helps to overcome the consequences of the use of different thresholds for the non infected status.

The central tendency reported in the review of Hortet and Seegers [32] was, for the daily study level, a decrease of $0.5 \mathrm{~kg}$ per two-fold increase of crude SCC ( 0.4 in primiparous and 0.6 in multiparous cows). A further assessment by Hortet et al. [33], based on French data, found the same magnitude in average losses as that in the cited review paper. Moreover, this latter study also showed that the magnitude of the loss was influenced both by the lactation number and by lactation stage (at least in parities higher than the first one). Quite surprisingly, when considering that milk yield of a cow is higher in early lactation, the losses were found to be higher, at the same SCC value, in late rather than in early lactation. This is illustrated in Figure 2. In another recent paper [37], based on a large Swedish dataset, similar magnitude of losses as the cited review was found in multiparous cows: the loss was $2.04 \mathrm{~kg}$ per unit 


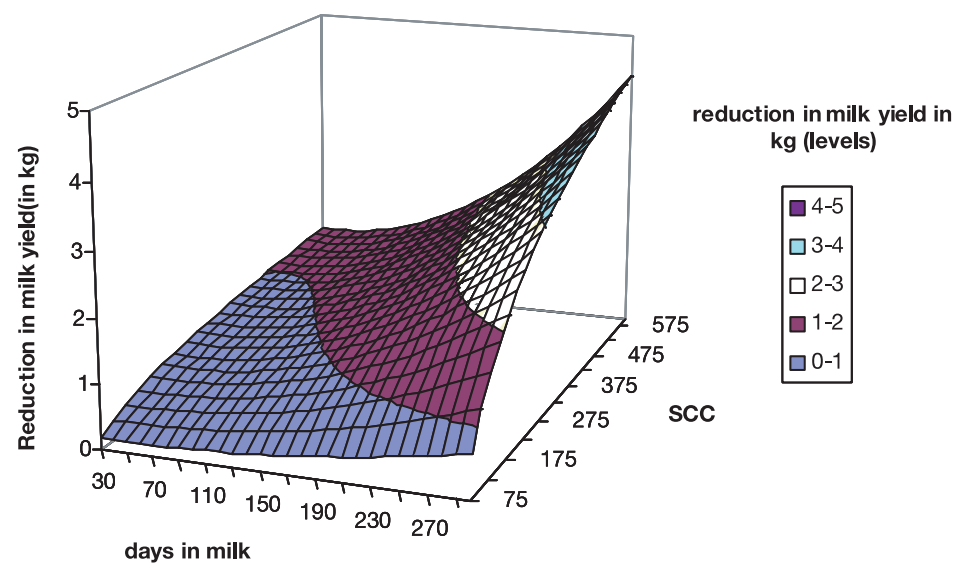

Figure 2. Reduction in milk yield according to SCC and days in milk for cows in 2nd lactation (reproduced from [33] with permission).

of increase in $\log _{10}\left(\mathrm{SCC} .10^{-3}\right)$, which corresponded to about $0.6 \mathrm{~kg}$ per two-fold increase of crude SCC. The authors found a slightly lower loss in primiparous cows (half of that calculated for multiparous cows). To assess the milk loss, these authors used pre-corrected yields with fixed adjustment effects calculated from only the non infected test-days. Logically this should have resulted in higher estimates for losses, when compared to the previously used method of analysis, but this was not the case. No obvious explanation can be hypothesised to explain this observation.

Differences in SCC lactation curves have been described according to the pathogen involved in the infection process (e.g., De Haas et al. [17]). An unsolved question is then: are the losses dependent on the nature of the pathogen or are they only dependent on the inflammation magnitude measured by SCC?

The effects of parity and lactation number described in Hortet et al. [33] have to be confirmed. Until now, as for the consequences of clinical cases, no real reliable assessment of an influence of the production level on the magnitude of the loss has been done: the production level was only statistically accounted for in some studies, like in Koldeweij et al. [37]. Statistical analysis models used to answer this difficult point should cover two aspects: production as a risk factor, as already mentioned, and the diluting effect of higher milk yield on SCC [20].

On the contrary to what is commonly accepted, an elevated SCC does not only represent the subacute or chronic inflammation of the udder but also the acute phases. Especially when the incidence of clinical phases is high, their impact is partially accounted for, due to the fact that the cows are usually sampled when the test-day falls just a few days after a clinical phase. In that time, the level of SCC has not decreased to normal and thus still reflects the consequence of the acute inflammation. This was probably the case in most of the studies. This leads then to an overestimation of the global milk loss, when adding the elevated SSC effect and the clinical cases effect. Further studies should pay more attention to this problem.

To summarise, the effect of SCC on individual cow yield can conservatively be accounted for by a decrease of $0.5 \mathrm{~kg}$ per two-fold increase of SCC starting over 
50000 cells $/ \mathrm{mL}$. When needed, more precise predictions according to lactation stage and lactation number can be made.

\subsection{Effects on milk composition and quality}

Fat and protein yields, as well as fat and protein contents of milk, are modified by intramammary infection, but quantification of these modifications on large samples remains scarce (for review: [31, 32]). As known for a long time, fat yields are depressed (for example: Philpot [49]). The main mechanism involved is the reduction of milk volume. Nevertheless it has still not yet been demonstrated whether every mastitis case gives a decrease in the fat content of the 4-quarter milk, although most studies conclude in favour of this trend [32]. This is due to the 4-quarter observation level: a possible effect can best be seen in onequarter milk when there is a severe clinical inflammation of that quarter. Regarding proteins, less knowledge exists. The total protein yield is also depressed [34, 37]), but most of the papers and arguments favour an apparent increased protein content of milk in association with an infection. This is due to the fact that protein content is estimated from the nitrogenic content of milk. The actual true casein content is depressed and inflammatory non coagulable proteins are increased $[4,5]$. In addition to this, the proteolytic activity of the milk is increased, which makes the problem greater for the cheese manufacturer.

To summarise, when looking at the lactational level and only to what is the farmer's main concern (impact on milk price), fat and protein contents are only very little modified, according to Houben et al. [34] and Myllis and Rautala [45]. Moreover, considering the withdrawal period after clinical case treatment, the loss in fat and protein yields can be considered quite proportional to the loss in milk quantity. Therefore, economic calculations can neglect the effects on milk composition, except where a special opportunity for high valorisation by specific milk pricing would exist.

Two aspects of quality are not detailed here. Mastitis also affects the bacterial count of the milk, but the elevation generated is almost negligible after the withdrawal period. Moreover, when errors occur, antibiotic treatments (for clinical cases or at drying-off) put the farm at a higher risk to experience positive results for growth inhibitor detection tests applied on the bulk tank milk.

\section{EFFECTS ON LONGEVITY AND OTHER PRODUCTION EFFECTS}

\subsection{Survival and longevity}

\subsubsection{Short term effect: lethality}

Only a few papers have dealt with the topic. Based on the annual mortality rates given in the original papers, we calculated a mastitis-attributable annual mortality rate of $0.22 \%$ in Holstein herds in western France [22] and $0.19 \%$ in dairy herds in Northern Ireland [43]. Gram negative pathogens lead to a higher fatality rate. This was shown by Bradley and Green [14] who reported a three-times higher specific mortality rate $(0.6 \%$ of the lactating cows) and a high fatality rate $(2.2 \%)$ in 6 herds, due to a high incidence of Gram-negative-bacteria induced clinical cases. Upon studying necropsy records, Hazlett et al. [28] already reported that, out of 145 cases that had bacteriological results, Escherichia coli was involved in $74 \%$ of them, Klebsiella sp. and Staphylococcus aureus in about $8 \%$ of them each.

\subsubsection{Mid term effect: longevity}

The effects of clinical mastitis and elevated somatic cell counts on longevity were recently included in the review of Beaudeau et al. [10]. Only one paper dealing with risk factors for the specific culling 
Table III. Effect of clinical mastitis and elevated SCC on relative risk for culling.

\begin{tabular}{cccc}
\hline Type of mastitis & Reference & Risk of culling & Additional information \\
\hline Clinical mastitis & Beaudeau et al. [8] & 1.5 & Diagnosis $<90 \mathrm{~d}$ on late culling (all lactation ranks) \\
Beaudeau et al. [9] & 4.0 & Diagnosis during the dry period in 1st lactation \\
& 1.3 & Diagnosis $<45 \mathrm{~d}$ in lactation $<3$ \\
& Gröhn et al. [27] & 1.9 & Diagnosis $<30 \mathrm{~d}$; on culling $<30 \mathrm{~d}$ \\
& 3.0 & $60<$ diagnosis $<150 \mathrm{~d}$; on $120<$ culling $<180 \mathrm{~d}$ \\
& Rajala-Schultz & 1.4 & \\
et al. [51] & to 2.6 & \\
Elevated SCC & Beaudeau et al. [9] & 1.2 & $\mathrm{SCC}=300000-800000 \mathrm{c} / \mathrm{mL}$; throughout lactation 1 \\
& 1.7 & $\mathrm{SCC} \geq 800000 \mathrm{c} / \mathrm{mL}$; throughout lactation 1 \\
\hline
\end{tabular}

reason 'mastitis' has been published since [52].

The impact of clinical mastitis and elevated SCC in the culling process can simply be described by culling reasons. Among health-related culling reasons, those related to udder disorders were the second most frequent: mastitis-related reasons counted for 5 to $17 \%$ of all culling circumstances $[7,21$, 56], and reached $28.5 \%$ when high SCC and teat injury were added [60]. However, declared culling reasons are more or less subjective, and therefore they rather provide information on the farmer's reactions than constitute an objective evaluation of the impact of health disorders on longevity.

Another approach consists of quantifying the effect of mastitis on the risk of culling, mainly on a lactational basis and ignoring the culling reason. Logistic regression or survival analysis were used to provide risk estimates associated with mastitis and/or elevated SCC, which were most of the time adjusted for other putative risk factors (other health disorders, reproductive performance, milk yield, parity, etc.). The recent results are displayed in Table III. The study of Roxström and Strandberg [52] considered cows culled for mastitis as the declared culling reason. An increased risk of culling in cows that have experienced clinical mastitis or elevated SCC is reported in all available studies, regardless of the differences between breeds, study periods and designs. The risk of being more rapidly culled after clinical mastitis occurrence exists for all stages of lactation. However, cases occurring in early lactation $[8,27]$ and during the dry period [9] are associated with the highest risk. Culling subsequent to mastitis occurs either very early in lactation, probably in relation to milking disability, or is delayed to the end of lactation $[52,56]$. A substantially increased risk of culling consecutive to teat injuries has also been reported by Beaudeau et al. [7, 8], probably because these disorders can disable a quarter or increase the risk for mastitis.

The differential impact of clinical mastitis, depending on its stage of lactation of occurrence shows that farmers mainly account for subsequent and future milk yield to make the culling decision. The effect of mastitis on the subsequent shortterm milk yield (cf. supra) may partly explain why mastitis occurring before the peak of lactation has a large impact on culling. Gröhn et al. [27] showed that the impact of mastitis occurring within $30 \mathrm{~d}$ postpartum on culling was mainly indirect, i.e. mediated through lower milk yield. Indeed, its effect was no longer significant in models containing a descriptor of subsequent milk yield. Furthermore, despite a 
low incidence rate, mastitis during the dry period is probably associated with a decrease of the expected yield in the next lactation, or, in some countries, a fear of the consequences of an Actinomyces pyogenes infection.

To summarise, the risk for a cow of being culled following the occurrence of clinical mastitis or elevated SCC is increased by a factor of 1.5 to 5, mainly depending on the severity of the milk drop and the farmer's anticipation concerning the future yield of the cow.

\subsection{Other effects}

\section{Feed intake}

Only peripartum clinical mastitis was studied. It was associated to a significant decrease of dry matter intake and estimated net energy supply before and after calving [67]. However in this study, $2 / 3$ of the mastitis cases were preceded or concomitant with other disorders. Therefore, the observed depression of intake cannot be attributed to mastitis only.

\section{Loss in body weight}

On the contrary to metabolic disorders, acute clinical mastitis does not quite depress the body weight. Only a non significant effect was described by Østergaard and Gröhn [46] in multiparous cows during the week of occurrence.

\section{ECONOMIC IMPACT OF MASTITIS AND ECONOMICS OF MASTITIS CONTROL}

The latest review of papers dealing with mastitis economics was done by Schepers and Dijkhuizen in 1991 [53]. Several new studies have been published since. Most deal with the economics of control, and sometimes only with partial aspects like culling of mastitic cows [35,61], rather than with the question of the measurement of the whole economic impact of the disease.

\subsection{Methodological issues}

To assess the direct economic impact of mastitis, costs (i.e. extra-resources used) and losses (i.e. reduced revenues) have to be quantified and aggregated. To allow a comparison of decisions for health management, it is necessary to use a marginal approach, based on the comparison of the output/input ratio [42]. The choice of an alternative control plan instead of the current one, is grounded when the losses avoided by this new control plan are larger than the additional costs of this plan (Fig. 3).

Control costs include expenditures which can be measured directly from invoices or calculated according to standard treatment and prevention costs, and from labour time for treatment and prevention. Losses correspond to not earned monetary incomes. They are first calculated from the direct modifications of milk price, especially those due to penalties for high SCC. In addition to that, an economic translation

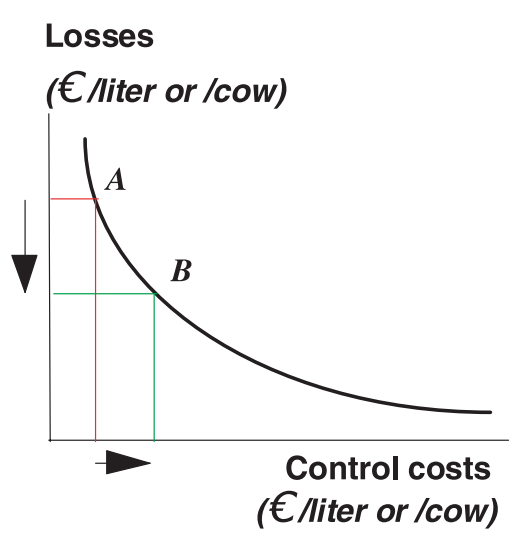

Figure 3. Conceptual approach for costeffectiveness assessment in a modified control plan for mastitis (avoided losses have to be larger than additional costs when moving from A to B). 


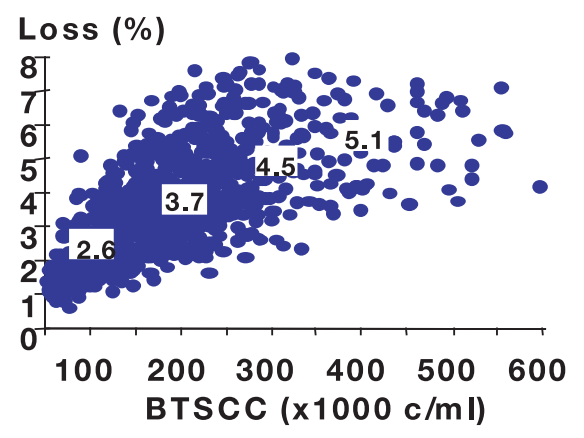

Figure 4. Calculated herd-level loss at a testday according to BTSCC (somatic cell count of bulk tank milk) for dairy herds in western France [57].

of two types of effects is needed: (i) the decrease of the herd productivity through the several so-called production effects; and (ii) the non-ability of the milk produced for sale (withdrawal after treatments or rejection from collection).

The economics of mastitis needs to be addressed at the farm level. The relationship between the bulk tank milk somatic cell count (BTSCC) and the herd-level loss in milk yield is not directly the same as at an individual test-day level. Compared to the individual level, herd-level losses are higher for low values in BTSCC and lower for high values (see Fig. 4 to illustrate this point). The herd level also implies integrating the decisions made by farmers, often with incomplete information, in addition to the basic biological facts. Therefore some herd-level effects are not strictly limited to the aggregation of basic individual effects. Moreover, at the herd level, some compensation or buffer mechanisms can act [58]. For example, a farmer decides to cull cows with high SCC, more based on the BTSCC and the milk pricing system, than on the absolute values of the individual SCC results of the cows. For another example, a farmer can decide to cull an extra-cow to decrease the BTSCC and give up to sell a heifer. This should be accounted for and is rather complex to model.
Two main groups of approaches have been used in mastitis economics:

(1) The first one is only observational and tries to assess the effect associated from an observed variation in economic results within a sample of farms, comparing high vs. low prevalence or with vs. without the implementation of a control action. The economic variables considered in that case are often simple and can be limited to milk price or revenue from delivered milk, more or less diminished for some control action costs, like in Ott and Novak [47]. More elaborated economic results, like gross margin or net profit, are influenced by much heavier factors and confusion may occur. This is complicated by the fact that farmers often modify their herd management. This group of approaches provides thus incomplete or possibly confounded results.

(2) The second group of approaches relies on modelling and simulation. The most frequent strategy is a combination of results from an observational study and further modelling-simulation steps. Observed data address the variation in occurrence and/or the variation in technical effects in a surveyed sample of farms after/before or with/ without the implementation of control plans. Modelling-simulation steps are then applied to these data to calculate the production effects and/or the economic consequences [1, 25, 26, 44]. Sometimes variation in the occurrence of mastitis, technical production effects and economic effects are all simulated [13, 68]. Complete validation of the simulation tools can sometimes become problematic, due to the absence of the needed data to conduct a goodness-of-fit procedure.

Partial budgeting is a commonly used technique to express the economic differences in the second group of approaches. This technique allows to perform a static comparison between "high" and "low" (or null) prevalence situations, the first one being mostly an observed situation (from a survey, for example, or from a typical herd 
Table IV. Components included in the partial budget simulation of Fourichon et al. $[24,26]$ to calculate the economic impact of mastitis (case of no quota constraint).

\begin{tabular}{|c|c|}
\hline Unfavourable consequences & Favourable consequences \\
\hline Decrease in revenues & Increase in revenues \\
\hline $\begin{array}{l}\text { Lower milk sales (decreased yield and discarded milk) } \\
\text { Lower milk price } \\
\text { Lower calf sales } \\
\text { Lower meat sales (cows euthanasied, lower carcass } \\
\text { weight, lower carcass price) } \\
\text { Dead cows } \\
\text { Opportunity costs: margin on hectares used for raising } \\
\text { extra heifers }\end{array}$ & $\begin{array}{l}\text { Higher calf sales due to extra } \\
\text { replacement heifers } \\
\text { Higher meat sales (extra culls, higher } \\
\text { carcass weight) }\end{array}$ \\
\hline Increase in costs & Decrease in costs \\
\hline $\begin{array}{l}\text { Costs for extra calves up to } 15 \mathrm{~d} \text { (milk replacer, calf } \\
\text { veterinary costs, identification costs) } \\
\text { Costs for raising heifers from } 15 \mathrm{~d} \text { to } 1 \text { st calving to } \\
\text { replace extra culled cows (milk replacer, concentrates, } \\
\text { veterinary costs, identification, variable costs for land } \\
\text { hectares used for extra heifers) }\end{array}$ & $\begin{array}{l}\text { Lower use of concentrates } \\
\text { Lower use of milk replacer (discarded } \\
\text { milk given to calves) } \\
\text { Costs for calves due to reduction in calf } \\
\text { number (milk replacer, calf veterinary } \\
\text { costs, identification costs) }\end{array}$ \\
\hline
\end{tabular}

in a country) and the second a simulated one $[1,11,15,29,38,42,44,66]$. Table IV displays, as an example, the components included by Fourichon et al. [24, 26] in their economic calculation model when there is no quota constraint. Since designed for a French context, and given the strict quota regulation (no transfer between farms without purchasing or borrowing land), the calculation model proposed by these authors could also simulate and assess the consequences of delivering the allowed quota with more cows (and heifers) than needed (because of the lower production caused by mastitis). This was the most prevalent case in the survey of Fourichon et al. [25] conducted in western France.

Dynamic modelling is a more sophisticated and more relevant way to assess the economic worthiness of a control plan. This technique allows consideration of transient situations and costs $[12,13,58]$. Linear programming and dynamic programming techniques have been implemented several times in economic models applied to farm management and sometimes to mastitis control: recently, by Houben et al. [35] and Zepeda et al. [68]. There are limits to these deterministic approaches. They imply infinite divisibility of factors, linearity and additivity of effects, and also the certainty of effects. Thus, these techniques are well adapted to optimisation procedures in cases of absence of uncertainty, while in mastitis economics, a large part of the decision making is supported by imperfect knowledge. Therefore simulation techniques mimicking the farmer's decision process and including stochastic effects to model uncertainty and variability are more relevant than the deterministic programming approaches $[1,36]$.

As underlined by Seegers et al. [55], any value for the economic burden due to mastitis (as for any other clinical disorder), in a herd or a country is, per se, of low external validity. Indeed, variations in the prevalence of mastitis and in the nature of pathogens involved are aggregated with: (i) differences in the farming system, herd management and implementation rules of 
Table V. Components included in simulations to assess the economic impact or the economic efficiency of control plans for mastitis in recent literature.

\begin{tabular}{|c|c|c|c|c|c|c|c|c|c|c|c|c|c|}
\hline \multirow[t]{2}{*}{ Component } & \multicolumn{13}{|c|}{ Reference of paper ${ }^{(1)}$} \\
\hline & 1 & 2 & 3 & 4 & 5 & 6 & 7 & 8 & 9 & 10 & 11 & 12 & 13 \\
\hline $\begin{array}{l}\text { Decreased milk yield } \\
\text { or higher number of cows }\end{array}$ & $\mathrm{X}$ & $\mathrm{X}$ & $\mathrm{X}$ & $\mathrm{X}$ & $\mathrm{X}$ & $\mathrm{X}$ & $\mathrm{X}$ & $\mathrm{X}$ & $\mathrm{X}$ & $\mathrm{X}$ & & $\mathrm{X}$ & $\mathrm{X}$ \\
\hline Variation in milk composition & & & & & & & & $\mathrm{X}$ & & $\mathrm{X}$ & & $\mathrm{X}$ & $\mathrm{X}$ \\
\hline Veterinary costs & $\mathrm{X}$ & $\mathrm{X}$ & $\mathrm{X}$ & $\mathrm{X}$ & $\mathrm{X}$ & & $\mathrm{X}$ & $\mathrm{X}$ & $\mathrm{X}$ & $\mathrm{X}$ & & $\mathrm{X}$ & $\mathrm{X}$ \\
\hline Treatment costs & $\mathrm{X}$ & $\mathrm{X}$ & $\mathrm{X}$ & $\mathrm{X}$ & $\mathrm{X}$ & $\mathrm{X}$ & $\mathrm{X}$ & $\mathrm{X}$ & $\mathrm{X}$ & $\mathrm{X}$ & & $\mathrm{X}$ & $\mathrm{X}$ \\
\hline Mortality and extra-culling & & $\mathrm{X}$ & $\mathrm{X}$ & $\mathrm{X}$ & $\mathrm{X}$ & & $\mathrm{X}$ & $\mathrm{X}$ & $\mathrm{X}$ & $\mathrm{X}$ & & $\mathrm{X}$ & $\mathrm{X}$ \\
\hline Extra-manpower & $\mathrm{X}$ & & & $\mathrm{X}$ & $\mathrm{X}$ & & $\mathrm{X}$ & & & $\mathrm{X}$ & & & \\
\hline $\begin{array}{l}\text { Penalties, milk produced } \\
\text { and not sold }\end{array}$ & $\mathrm{X}$ & & & & $\mathrm{X}$ & $\mathrm{X}$ & & $\mathrm{X}$ & & & & $\mathrm{X}$ & $\mathrm{X}$ \\
\hline Decrease in feed intake & & $\mathrm{X}$ & $\mathrm{X}$ & & & & $\mathrm{X}$ & & & & & $\mathrm{X}$ & $\mathrm{X}$ \\
\hline
\end{tabular}

(1) Authors: 1: DeGraves and Fetrow [16]; 2: McInerney et al. [42]; 3: Beck et al. [11]; 4: Hillerton et al, [29]; 5: Miller et al. [44]; 6: Van Eenennaam et al., [62]; 7: Kossaibati and Esslemont [38]; 8: Allore and Erb [1]; 9: Bennett et al. [13]; 10: Zepeda et al. [68]; 11: Yalcin et al. [65; 66]; 12: Fourichon et al. [24, 26]; 13: Seegers et al. [58, 59].

treatments; (ii) differences in the upper limit of milk production (fixed quota, possible leasing of quota or no quota); (iii) differences in milk pricing according to tank SCC; and (iv) other differences in prices of production factors. Last point, but not least, when considering the available literature, it appears that the components included in various simulations differ widely, as illustrated in Table V. Therefore, it is not very relevant to compare the results obtained in different spatio-temporal contexts. Thus only some examples will be presented below.

\subsection{Recent examples of questions studied and results}

\subsubsection{Measurement of the impact of mastitis}

Some examples are given here (the comparisons between studies are almost not valid, cf. above):

- Dealing only with somatic cell counts and under the pricing system applied in
Ontario, Dekkers et al. [18] showed that the impact of one unit in herd average linear somatic cell score ( $\log 2$ transformed), i.e. for a two-fold increase, was 19.6 Can. \$ per cow-year.

- The calculated total economic impact of clinical mastitis was found to be $119 £$ per cow-case and was mainly due to reduced yield and discarded milk. This was $38 \%$ of the total impact of common clinical health problems in a group of 90 dairy farms from the United Kingdom in 1995 [38]. Also for UK conditions, losses were assessed reaching 121 Million $£$ for a mid-incidence level for mastitis $(50 \%)$ at the country level, by Bennett et al. [13].

- The average cumulated impact of mastitis (clinical and elevated SCC) was $78 €$ per cow-year (around $11 €$ per $1000 \mathrm{~L}$ of milk) in a study involving 197 herds in western France. Mastitis accounted for $33 \%$ of the total impact calculated for health disorders in the surveyed herds [25, 26]. Average mastitis related losses were 
two-times higher than mastitis related control costs, representing respectively 22 and $11 \%$ of the total impact of the health disorders. A questionable point, in assessing the total impact of mastitis, is that the calculations of losses need to fix a reference "low" level, which can theoretically be set to zero in the incidence of clinical cases and about 100000 cells $/ \mathrm{mL}$ in SCC. As long as a zero value in annual incidence is never quite observed, except in small herds, using such a reference leads to a slight overestimation. Therefore, it is advisable to use a more realistic reference level. Authors set that level at the 10th percentile of the clinical incidence in their survey.

\subsubsection{Assessment of worthiness of control actions}

Some examples of recent results for economic worthiness of control actions are also available (the comparisons between studies are almost not valid, cf. above):

- Using partial budgeting applied to outcomes of a discrete event stochastic model and under US conditions, Allore and coauthors [1, 2, 3] found that, both prevention (forestripping, predipping, cleaning and drying with a single use paper towel and postdipping) and dry cow therapy were relevant in mastitis control strategies for herds having BTSCC over 500000 cells/ $\mathrm{mL}$. Where environmental pathogens are predominant, strategies including vaccination for $E$. coli mastitis provide higher annual profit per cow than strategies not including that vaccine.

- Using a calculation of marginal returns (i.e. the sum of the value of the saved production and of the avoided BTSCC penalties) provided by several control measures applied to herds facing a high BTSCC problem ( $>400000$ cells $/ \mathrm{mL}$ ), Yalcin et al. [66] found a total impact of $100 £$ per cowyear in Scotland. The authors concluded that, out of these $100 £$, one third could have been saved by using more efficient control measures (dry cow therapy, milk- ing machine test and post-milking teat disinfection). However, the technical results of the study came from a static comparison (logistic regression) of farms implementing and farms not implementing the measures. Therefore, these conclusions do not necessarily apply to changes in control plans applied on the same farms, which would probably have been more relevantly studied by a dynamic simulation approach.

- Profits of a control programme to reduce the prevalence of Staphylococcus aureus infections are most dependent on the initial prevalence of mastitis and initial BTSCC penalty or premium, than on milk yield or the cost of drying-off treatments, under the US context [68].

- An important contribution to the benefit of mastitis control might originate in a reduction of persistently infected cows by culling, as shown by Yalcin et al. [66], using dynamic programming.

- By comparing several options for control plans applied to high BTSCC herds by a dynamic simulation model, Seegers et al. $[58,59]$ concluded that, under French conditions, the control strategies including strict culling rules for cows having persistently high SCC, are not relevant in herds with BTSCC above 300000 cells $/ \mathrm{mL}$ and delivering their milk quotum, despite a high mastitis prevalence. Although very effective in decreasing BTSCC rapidly when combined with improved prevention, strict culling rules frequently lead to not reaching the quota. This resulted in a lower gross margin, given the (relatively mild) French penalty system for BTSCC and the (rigid) French quota system. Lactational antibiotic treatment of newly incident infections in young cows could be advisable in such cases. Applying strict culling rules becomes more relevant under 300000 cells $/ \mathrm{mL}$ in BTSCC (then, they concern less cows and the quota will be more easily fulfilled). The interest of culling is higher when the contagious aspect of mastitis is higher. 


\section{CONCLUSION}

The economic impact of mastitis results from two origins: the control costs (i.e. extra resource use) and the losses (i.e. reduced revenues). Losses are the economic consequences of the production effects and are quite often difficult to assess. The main detrimental production effect induced by mastitis is a more or less persistent decrease in milk yield. Milk composition changes can almost be neglected in economic calculations. Lethality rate for clinical mastitis is very low, except for specific situations of high prevalence of Gram negative infections. Mastitis exposes the cows to a higher risk to experience anticipated culling. Translating these production effects into economic losses has to be done for a specific farm and a specific economic context. Therefore, the results regarding the economic impact of mastitis or the worthiness of control plans should rather not be directly compared.

\section{REFERENCES}

[1] Allore H.G., Erb H.N., Partial budget of the discounted annual benefit of mastitis control strategies, J. Dairy Sci. 81 (1998) 22802292.

[2] Allore H.G., Schruben L.W., Erb H.N., Oltenacu P.A., Design and validation of a dynamic discrete event stochastic simulation model of mastitis control in dairy herds, J. Dairy Sci. 81 (1998) 703-717.

[3] Allore H.G., Erb H.N., Schruben L.W., Oltenacu P.A., A simulation of strategies to lower tank somatic cell count below 500000 per milliliter, J. Dairy Sci. 81 (1998) 694-702.

[4] Auldist M.J., Coats S., Sutherland B.J., Mayes J.J., McDowell G.H., Rogers G.L., Effects of somatic cell count and stage of lactation on raw milk composition and the yield and quality of Cheddar cheese, J. Dairy Res. 63 (1996) 269-280.

[5] Barbano D.M., Rasmussen R.R., Lynch J.M., Influence of milk somatic cell count and milk age on cheese yield, J. Dairy Sci. 74 (1991) 369-388.
[6] Bartlett P.C., Van Wijk J., Wilson D.J., Green C.D., Miller G.Y., Majewski G.A., Heider L.E., Temporal patterns of lost milk production following clinical mastitis in a large Michigan Holstein herd, J. Dairy Sci. 74 (1991) 1561-1572.

[7] Beaudeau F., Henken A., Fourichon C., Frankena K., Seegers, H., Associations between health disorders and culling of dairy cows: a review, Livest. Prod. Sci 35 (1993) 213-236.

[8] Beaudeau F., Frankena K., Fourichon C., Seegers H., Faye B., Noordhuizen J.P.T.M., Associations between health disorders of French dairy cows and early and late culling decision making within the lactation, Prev. Vet. Med. 19 (1994) 213-231.

[9] Beaudeau F., Ducrocq V., Fourichon C. Seegers H., Effect of disease on length of productive life of French Holstein dairy cows assessed by survival analysis, J. Dairy Sci. 78 (1995) 103-117.

[10] Beaudeau F., Seegers H., Ducrocq V., Fourichon C., Bareille N., Effect of health disorders on culling in dairy cows: a review and a critical discussion, Ann. Zootech. 49 (2000) 293-311.

[11] Beck H.S., Wise W.S., Dodd F.H., Cost benefit analysis of bovine mastitis in the UK, J. Dairy Res. 59 (1992) 449-460.

[12] Bennet R.M., The use of "economic" quantitative modelling techniques in livestock health and disease-control decision making: a review, Prev. Vet. Med. 13 (1992) 63-76.

[13] Bennett R., Christiansen K., Clifton-Hadley R., Preliminary estimates of the direct costs associated with endemic diseases of livestock in Great Britain, Prev. Vet. Med. 39 (1999) 155-171.

[14] Bradley A.J., Green M.J., Aetiology of clinical mastitis in six Somerset dairy herds, Vet. Rec. 148 (2001) 683-686.

[15] DeGraves F.J., Fetrow J., Partial budget analysis of vaccinating dairy cattle against coliform mastitis with an Escherichia coli J5 vaccine, J. Am. Vet. Med. Assoc. 199 (1991) 451-455.

[16] DeGraves F.J., Fetrow J., Economics of mastitis and mastitis control, Vet. Clin. North Am. Food Anim. Pract. 9 (1993) 21-34.

[17] De Haas Y., Barkema H.W., Veerkamp R.F, The effect of pathogen-specific clinical mastitis on the lactation curve for somatic cell count, J. Dairy Sci. 85 (2002) 1314-1323

[18] Dekkers J.C.M., Van Erp T., Schukken Y.H., Economic benefit of reducing somatic cell 
count under the milk quality program of Ontario, J. Dairy Sci. 79 (1996) 396-401.

[19] Deluyker H.A., Gay J.M., Weaver L.D., Azari A.S., Change of milk yield with clinical diseases for a high producing dairy herd, J. Dairy Sci. 74 (1991) 436-445.

[20] Emanuelson U., Funcke H., Effect of milk yield on relationship between bulk milk somatic cell count and prevalence of mastitis, J. Dairy Sci. 74 (1991) 2479-2483.

[21] Esslemont R.J., Kossaibati M.A., Culling in 50 dairy herds in England, Vet. Rec. 140 (1997) 36-39.

[22] Faye B., Pérochon L., La mortalité des vaches laitières dans l'enquête écopathologique Bretagne, Vet. Res. 26 (1995) 124-131.

[23] Firat M.Z., An investigation into the effects of clinical mastitis on milk yield in dairy cows, Livest. Prod. Sci. 36 (1996) 311-321.

[24] Fourichon C., Seegers H., Beaudeau F., Bareille N., Economic losses consecutive to health disorders in dairy farms in Pays de la Loire (France), 52nd Meeting of the European Association of Animal Production, Budapest (H), 26-29 August 2001.

[25] Fourichon C., Seegers H., Beaudeau F., Verfaille L., Bareille N., Health-control costs in dairy farming systems in western France, Livest. Prod. Sci. 68 (2001) 141-156.

[26] Fourichon C., Seegers H., Bareille N., Beaudeau F., Évaluation des pertes et de l'impact économiques consécutifs aux principaux troubles de santé en élevage bovin laitier, Rencontres Recherches Ruminants, 5-6 décembre, Paris, 8 (2001) 137-143.

[27] Gröhn Y.T., Eicker S.W., Ducrocq V., Hertl J.A., Effect of diseases on the culling of Holstein dairy cows, J. Dairy Sci. 81 (1998) 966978.

[28] Hazlett M.J., Little P.B., Maxie M.G., Barnum D.A., Fatal Mastitis of dairy cows, Can. J. Comp. Med. 48 (1984) 125-129.

[29] Hillerton J.E., West J.G.H., Sheran M.F.H., The cost of summer mastitis, Vet. Rec. 131 (1992) 315-317.

[30] Hoblet K.H., Schnitkey G.D., Arbaugh D., Hogan J.S., Smith K.L., Schoenberger P.S., Todhunter D.A., Hueston W.D., Pritchard D.E., Bauman G.L., Haider L.E., Brockett B.L., Conrad H.R., Costs associated with selected preventive practices and with episodes of clinical mastitis in nine herds with low somatic cell counts, J. Am. Vet. Med. Assoc. 199 (1991) 190-196.

[31] Hortet P., Seegers H., Calculated milk production losses associated with elevated somatic cell counts in dairy cows: review and critical discussion, Vet. Res. 29 (1998) 497 510.

[32] Hortet P., Seegers H., Milk yield loss and related composition changes resulting from clinical mastitis in dairy cows: a review, Prev. Vet. Med. 37 (1998) 1-20.

[33] Hortet P., Beaudeau F., Seegers H., Reduction in milk yield associated with somatic cell counts up to 600000 cells $/ \mathrm{mL}$ in French Holstein cows without clinical mastitis, Livest. Prod. Sci. 61 (1999) 33-42.

[34] Houben E.H.P., Dijkhuizen A.A., Van Arendonk J.A.M., Huirne R.B.M., Short- and long-term production losses and repeatability of clinical mastitis in dairy cattle, J. Dairy Sci. 76 (1993) 2561-2578.

[35] Houben E.H.P., Huirne R., Dijkhuizen A.A, Kristensen A.R., Optimal replacement of mastitic cows determined by a hierarchic Markov process, J. Dairy Sci. 77 (1994) 2975-2993.

[36] Jalvingh A.W., The possible role of existing models in on-farm decision support in dairy cattle and swine production, Livest. Prod. Sci. 31 (1992) 351-365.

[37] Koldeweij E., Emmanuelson U., Janson L., Relation of milk production loss to milk somatic cell count. Acta Vet. Scand. 40 (1999) 47-56.

[38] Kossaibati M.A., Esslemont R.J., The costs of production diseases in dairy herds in England, Vet. J. 154 (1997) 41-51.

[39] Laevens H., Deluyker H., Schukken Y.H., De Meulemeester L., Vandermeersch R., De Muêlenaere E., De Kruif A., Influence of parity and stage of lactation on the somatic cell count in bacteriologically negative dairy cows, J. Dairy Sci. 80 (1997) 3219-3226.

[40] Lescourret F., Coulon J.B., Modelling impact of mastitis on milk production by dairy cows, J. Dairy Sci. 77 (1994) 2289-2301.

[41] Luquet F., Calavas D., Bugnard F., Incidences des mammites cliniques sur les courbes de lactation des vaches laitières, Epidémiol. Santé Anim. 22 (1992) 121-127.

[42] McInerney J.P., Howe K.S., Schepers J.A., A framework for the economic analysis of disease in farm livestock, Prev. Vet. Med. 13 (1992) 137-154.

[43] Menzies F.D., Bryson D.G., McCallion T., Matthews D.I., A study of mortality among sucker and dairy cows in Northern Ireland in 1992, Vet. Rec. 137 (1995) 531-536.

[44] Miller R.H., Bartlett P.C., Lance S.E.E., Anderson J., Heider L.E., Costs of clinical mastitis and mastitis prevention in dairy 
herds, J. Am. Vet. Med. Assoc. 202 (1993) 1230-1236.

[45] Myllys V., Rautala H., Characterization of clinical mastitis in primiparous heifers, J. Dairy Sci. 78 (1995) 538-545.

[46] Østergaard S., Gröhn Y.T., Effects of diseases on test day milk yield and body weight of dairy cows from Danish research herds, J. Dairy Sci. 82 (199) 1188-1201.

[47] Ott S.L., Novak P.R., Association of herd productivity and bulk-tank somatic cell counts in US dairy herds in 1996, J. Am. Vet. Med. Assoc. 219 (2001) 1325-1330.

[48] Pedraza C.G., Efecto de la mastitis clínica sobre la producción de leche, Agricultura Técnica 51 (1991) 298-305.

[49] Philpot W.N., Influence of subclinical mastitis on milk production and milk composition, J. Dairy Sci. 50 (1967) 978.

[50] Rajala-Schultz P.J., Gröhn Y.T., Culling of dairy cows. Part I. Effects of diseases on culling in Finnish Ayrshire cows, Prev. Vet. Med. 41 (1999) 195-208.

[51] Rajala-Schultz P.J., Gröhn Y.T., McCulloch C.E., Guard C.L., Effects of clinical mastitis on milk yield in dairy cows, J. Dairy Sci. 82 (1999) 1213-1220.

[52] Roxström A., Strandberg E., Genetic analysis of functional, fertility-, mastitis-, and production-determined length of productive life in Swedish dairy cattle, Livest. Prod. Sci. 74 (2002) 125-135.

[53] Schepers J.A., Dijkhuizen A.A., The economics of mastitis and mastitis control in dairy cattle: a critical analysis of estimates published since 1970, Prev. Vet. Med. 10 (1991) 213-224.

[54] Schepers J.A., Lam T.J.G.M., Schukken Y.H., Wilmink J.B.M., Hanekamp W.J.A., Estimation of variance components for somatic cell counts to determine thresholds for uninfected quarters, J. Dairy Sci. 80 (1997) 1833-1840.

[55] Seegers H., Fourichon C., Malher X., L'Hostis M., A framework for animal health management, Vet. Res. 25 (1994) 165-173.

[56] Seegers H., Beaudeau F., Fourichon C., Bareille N., Reasons for culling in French Holstein cows, Prev. Vet. Med. 36 (1998) 257-271.

[57] Seegers H., Beaudeau F., Bareille N., Fourichon C., Informative value of the bulk milk somatic cell count of a dairy herd, 51st Meeting of the European Association of Animal Production, The Hague (NL), 21-24 August, 2000.
[58] Seegers H., Fourichon C., Sørensen J.T., Hortet P., Billon D., Modelling the cost-benefits of prevention and control of mastitis in dairy herds, Symposium on Economic Modelling of Animal Health and Farm Management, Wageningen University, Wageningen (NL), 23-24 November, 2000, pp. 55-61.

[59] Seegers H., Billon D., Fourichon C., Hortet $\mathrm{P}$., Evaluation de la pertinence économique du traitement des mammites subcliniques en cours de lactation, Rencontres Recherches Ruminants, Paris, 4-5 December, 9 (2002) 26-32.

[60] Stevenson M.A., Lean I.J., Descriptive epidemiological study on culling and deaths in eight dairy herds, Aust. Vet. J. 76 (1998) 482-488.

[61] Stott A.W., Kennedy J.O., The economics of culling dairy cows with clinical mastitis, Vet. Rec. 133 (1993) 494-499.

[62] Van Eenennaam A.L., Gardner I. A., Holmes J., Perani L., Anderson R.J., Cullor J.S., Guterbock M.N., Financial analysis of alternative treatments for clinical mastitis associated with environmental pathogens, J. Dairy Sci. 78 (1995) 2086-2095.

[63] Wilson D.J., Sears P.M., Clinical mastitis caused by different types of pathogens: differences in milk production loss, recovery, age at onset, and milk NAGase, Agri-Practice (1992) 13-8-13-21.

[64] Wolf J., Jahnke B., Beziehungen zwischen Eutergesundheit und Michleistung bei SMRkühen, Arch. Exper. Vet. Med. 44 (1990) 9-34.

[65] Yalcin C., Stott A.W., Dynamic programming to investigate financial impacts of mastitis control decisions in milk production systems, J. Dairy Res. 67 (2000) 515-528.

[66] Yalcin C., Stott A.W., Logue D.N., Gunn J., The economic impact of mastitis-control procedures used in Scottish dairy herds with high bulk-tank somatic-cell counts, Prev. Vet. Med. 41 (1999) 135-149.

[67] Zamet C.N., Colenbrander V.F., Erb R.E., Callahan C.J., Chew B.P., Moeller N.J., Variables associated with peripartum traits in dairy cows. II. Interrelationships among disorders and their effects on intake of feed and on reproductive efficiency, Theriogenology 11 (1979) 245-260.

[68] Zepeda L., Buelow K.L., Nordlund K.V., Thomas C.B., Collins M.T., Goodger W.J., Corrigendum to "A linear programming assessment of the profit to reduce prevalence of Staphylococcus aureus mastitis", [Prev. Vet. Med. 33 (1998) 183-193] Prev. Vet. Med. 44 (2000) 61-71. 